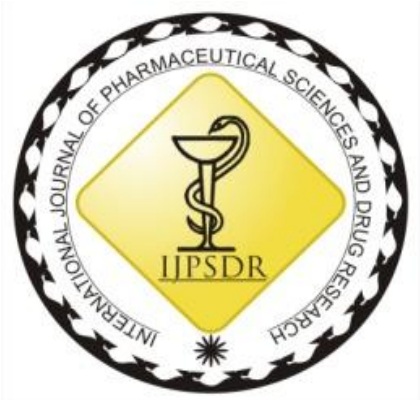

\author{
RESEARCH ARTICLE
}

ISSN: 0975-248X CODEN (USA): IJPSPP $($ (cc) EY-No-SA

\title{
Formulation Design and Optimization of Floating Matrix Tablets of Ciprofloxacin HCl by Using HPMC and Ethyl Cellulose with Experimental Design
}

\author{
Gourishyam Pasa*, Prasanta Kumar Choudhury, Ghanshyam Panigrahi, \\ Biswajeet Maharana \\ Department of Pharmaceutical Technology, Royal College of pharmacy and Health Sciences, Andhapasara Road,
Berhampur, Odisha, India
}

Copyright (C) 2019 Gourishyam Pasa et al. This is an open access article distributed under the terms of the Creative Commons AttributionNonCommercial-ShareAlike 4.0 International License which allows others to remix, tweak, and build upon the work non-commercially, as long as the author is credited and the new creations are licensed under the identical terms.

\begin{abstract}
The oral floating matrix tablets of Ciprofloxacin Hydrochloride were formulated by Experimental design by using HPMC $\mathrm{K}_{100} \mathrm{M}$ and Ethyl Cellulose as the retardant polymers each with three different levels with an approach to increase gastric residence and thereby improve drug bioavailability. From FTIR results it was confirmed that there is no chemical interaction between the drug with the excipients used in tablet formulations. Also, there was no shift in the endotherm of in the drug- excipients mixtures indicating compatibility of drug with all the excipients. All the tablets were prepared by effervescent approach in which Sodium bicarbonate was added as a gas generating agent. Floating Matrix tablets were prepared by direct compression method and prepared tablets were evaluated for weight variation, percentage friability, hardness and drug content studies. All the formulations showed compliance with pharmacopeia standards (I.P. 1996). Floating lag times of all the formulations were within 1 minute and Total floating time of all the formulations were more than 12 hours. In vitro release studies revealed that the release rate decreased with increase polymer proportion of retarding polymers. The formulation $\mathrm{CHE}_{9}$ sustained release of drug for 12 hours with 21\% release of drug after 1 hour and more than $97 \%$ at the end of 12 hours. From the Kinetic model it was found that the optimized formulation CHE9 showed linearity in case of Zero order ( $\mathrm{R}^{2}$ : 0.938$)$ and Higuchi model ( $\mathrm{R}^{2}$ : 0.954). By fitting data to Korsmeyer-Peppas model and ' $n$ ' value lying above 0.5 indicating non Fickian release.
\end{abstract}

Keywords: Oral floating matrix tablets, Experimental design, HPMC $\mathrm{K}_{100} \mathrm{M}$, Ethyl Cellulose, Ciprofloxacin Hydrochloride.

DOI: 10.25004/IJPSDR.2019.110102

Int. J. Pharm. Sci. Drug Res. 2019; 11(1): 07-15

*Corresponding author: Dr. Gourishyam Pasa

Address: Royal College of Pharmacy and Health Sciences, Andhapasara road, Berhampur Dist: Ganjam, Pin: 760002 Orissa, India

Tel.: +91-9861227645

E-mail $\bowtie$ : pasagourishyam@gmail.com

Relevant conflicts of interest/financial disclosures: The authors declare that the research was conducted in the absence of any commercial or financial relationships that could be construed as a potential conflict of interest.

Received: 22 October, 2018; Revised: 02 December, 2018; Accepted: 05 December, 2018; Published: 20 January, 2019

\section{INTRODUCTION}

A major constraint in oral controlled drug delivery is that not all drug candidates are absorbed uniformly throughout the gastrointestinal tract (GIT), and some drugs are absorbed only in a particular portion of GIT or absorbed to a different extent in various segments of 
the GIT. [1] Floating drug delivery systems are good promising options for drugs which show good absorption in the stomach and which are degraded, less efficient in the intestine. Gastro Retentive Drug Delivery System gets retained for longer period of time in stomach, thus helping in absorption of drug for the intended duration of time, which in turn improves bioavailability by reducing drug wastage, and improving solubility of drugs that are less soluble at high $\mathrm{pH}$ environment. It also helps in achieving local delivery of drug in the stomach and proximal small intestine. [2] Floating drug delivery systems (FDDS) have a bulk density less than gastric fluids and so remain buoyant in the stomach without affecting the gastric emptying rate for a prolonged period of time. While the system is floating on the gastric contents, the drug is released slowly at the desired rate from the system. After release of drug, the residual system is emptied from the stomach. [3] Ciprofloxacin belonging to the family of quinolones (term refers to potent chemotherapeutic antibacterial agents). It is a broadspectrum antibiotic active against both Gram-positive and Gram-negative bacteria. It functions by inhibiting DNA gyrase, a Type II topoisomerase and topoisomerase IV, enzymes necessary to separate bacterial DNA, thereby inhibiting cell division and also affects mammalian cell replication. It is used in the treatment of infections such as lower respiratory tract, urinary tract, bone and joint infections, hospital acquired infections, and diarrheal infections. Ciprofloxacin is a broad-spectrum antibiotic active against both Gram-positive and Gram-negative bacteria. It is absorbed completely (70\%) after oral administration and having a biological half-life of 3.5 to 4.5 hours. The drug should be administered twice a day; a rationale for developing Ciprofloxacin $\mathrm{HCl}$ as a gastro retentive dosage form, which is retained in the stomach for prolonged period of time and produces a constant input of drug to the absorption site. This improves bioavailability of the drug, reduces frequency of dosing, thus minimizing side effects. [4] The aim of the present study is formulation design and optimization of oral floating matrix tablets of Ciprofloxacin $\mathrm{HCl}$ by using Experimental Design. The objective of the present study is to formulate the Ciprofloxacin $\mathrm{HCl}$ floating tablets using $\mathrm{HPMC} \mathrm{K}_{100} \mathrm{M}$ and Ethyl Cellulose as the retardant polymers by direct compression techniques.

\section{MATERIALS AND METHODS}

\section{Materials}

Ciprofloxacin Hydrochloride was obtained as a gift sample from Dr Reddy's Lab (Hyderabad, India), HPMC $K_{100}$ and Ethyl Cellulose were obtained from Aurobindo Pharma Ltd, (Hyderabad, India), Micro Crystalline Cellulose and Mg. Stearate from Loba Chem (Mumbai, India). All other chemicals and ingredients were used for study are of commercial grade.

Methods

\section{Identification of drug}

The drug was identified by Infrared spectroscopy (IR), melting point determination and Ultraviolet spectroscopy (UV).

Infrared Spectroscopy [5]

Infrared (IR) spectra of received gift sample of drugs was performed in the range of $4000 \mathrm{~cm}^{-1}$ to $400 \mathrm{~cm}^{-1}$ by using FT-IR (DRS) technique (FT-IR-Affinity-1 spectrophotometer (DRS-8000) SHIMADZU, Japan) and studied for the presence of characteristic peaks.

\section{Ultraviolet Spectroscopy [6]}

The samples were subjected to UV Spectrophotometric analysis and were scanned for absorption maxima ( $\lambda \max$ ) in the range of 200 to $400 \mathrm{~nm}$ using UV-Visible Spectrophotometer in an appropriate medium and the same was compared with that of reference values in literature.

\section{Drug-polymer compatibility study}

It is well known that prior to the development of any dosage form with a new or old drug candidate, it is essential that certain fundamental physical and chemical properties of the drug molecule and other derived properties of the drug powder are determined. This information will dictate many of the subsequent events and possible approaches in formulation development. Hydrophilic polymers, as well as other excipients, contain reactive functional groups that may give rise to chemical and physical transformations. Thus, when studying new pharmaceutical formulations, it is important to verify the possibility of occurrence of incompatibilities between the components of the formulation.

\section{Fourier-Transform Infrared Spectroscopy (DRS)}

Fourier-transform infrared (DRS) spectra were obtained by using an FT IR-Affinity-1 spectrophotometer (DRS8000) SHIMADZU, Japan. The pure drug samples (Ciprofloxacin) were previously ground and mixed thoroughly with potassium bromide, an infrared transparent matrix, at 1:1 (Sample: KBr) ratio, respectively. The $\mathrm{KBr}$ powder was used as blank for background correction in FT-IR (DRS) studies. Forty five scans were obtained at a resolution of $4 \mathrm{~cm}-1$, from 4000 to $400 \mathrm{~cm}^{-1}$.

\section{Differential scanning calorimetry ${ }^{[7]}$}

The DSC measurements were performed on a DSC4000 (Seiko Instruments, Japan) differential scanning calorimeter with a thermal analyzer. All accurately weighed samples (about $2 \mathrm{mg}$ of sample or its equivalent) were placed in sealed aluminum pans, before heating under nitrogen flow $(20 \mathrm{ml} / \mathrm{min})$ at a scanning rate of $10^{\circ} \mathrm{C} \mathrm{min}-1$ from $50^{\circ} \mathrm{C}$ to $350^{\circ} \mathrm{C}$. An empty aluminum pan was used as reference.

Experimental design [8]

Some possible experimental trials, generated by application of $3^{2}$ factorial designs, were conducted to evaluate each independent factor at 3 levels. Formulation combinations $\left(\mathrm{CHE}_{1}-\mathrm{CHE}_{9}\right)$ using factorial design were shown in Table $3 \& 4$. The percentages of HPMC $\mathrm{K}_{100} \mathrm{M}\left(\mathrm{X}_{1}\right)$ and Ethyl Cellulose 
$\left(X_{2}\right)$ were chosen as control variables while, $Y_{1}$ (Cumulative $\%$ of drug released at 1 hour), $\mathrm{Y}_{6}$ (Cumulative $\%$ of drug released at 6 hour), $\mathrm{Y}_{12}$ (Cumulative \% of drug released at 12 hour) were selected as response variables by using Design Expert Software.

\section{Pharmacokinetic model [9-11]}

\section{Zero order kinetics}

Drug dissolution from pharmaceutical dosage forms that do not disaggregate and release the drug slowly (assuming that area does not change and no equilibrium conditions are obtained) can be represented by the following equation:

$$
\mathrm{W}_{0}-\mathrm{W}_{\mathrm{t}}=\mathrm{K}_{0} \mathrm{t}
$$

Where $W_{0}$ is the initial amount of drug in the pharmaceutical dosage form, $W_{t}$ is the amount of drug in the pharmaceutical dosage form at time $t$ and $k$ is proportionality constant. Dividing this equation by $W_{0}$ and simplifying: $f_{t}=k_{0} t$ Where $f_{t}=1-\left(W_{t} / W_{0}\right)$ and $f_{t}$ represents the fraction of drug dissolved in time $t$ and $\mathrm{k}_{0}$ the apparent dissolution rate constant or zero order release constant.

First order kinetics

This type of model to analyze drug dissolution study was first proposed by Gibaldi and Feldman and later by Wagner. The relation expressing this model:

$$
\log Q_{t}=\log Q_{0}+K_{1} t / 2.303 \text {. }
$$

Where $Q_{t}$ is the amount of drug released in time $t, Q_{0}$ is initial amount of drug in the solution and $K_{1}$ is the first order release rate constant.

\section{Korsmeyer -Peppas model}

Korsmeyer developed a simple semi empirical model, relating exponentially the drug release to the elapsed time $(\mathrm{t})$.

\section{$\mathrm{Qt} / \mathrm{Qa}=\mathrm{K}_{\mathrm{k}} \mathrm{t}^{\mathrm{n}}$}

Where $K_{k}$ is a constant incorporating structural and geometric characteristic of the drug dosage form and $n$ is the release exponent, indicative of the drug release mechanism.

Higuchi model

$Q_{t}=K_{H} t^{1 / 2}$ Where $Q_{t}=$ the amount of drug released at

\begin{tabular}{|c|c|}
\hline Release exponent (n) & Drug transport mechanism \\
\hline 0.5 & Fickian diffusion \\
\hline $0.5<n<1.0$ & Anomalous transport \\
\hline 1.0 & Case-II transport \\
\hline Higher than 1.0 & Super Case-II transport \\
\hline
\end{tabular}
time $t$ and $K_{H}=$ the Higuchi release rate.

Formulation development of matrix floating tablets of Ciprofloxacin Hydrochloride

Brief manufacturing procedure for Preparation of Ciprofloxacin floating matrix tablet

Matrix embedded controlled release tablets of Ciprofloxacin were prepared by direct compression technique using various concentrations of $\mathrm{HPCK}_{100} \mathrm{M}$ and Ethyl Cellulose. All the ingredients were sieved through the 40 mesh screen and mixed. All ingredients except Magnesium stearate and talc were blended in glass mortar uniformly. After the sufficient mixing of drug as well as other components, Magnesium stearate and Talc were added and mixed for additional 2-3 minutes. Microcrystalline cellulose was used as directly compressible vehicle. Magnesium stearate was used as lubricant and Talc was used as glidant. Finally after proper mixing, the powder mixture was compressed on a 10 station tablet compression machine (rotary tableting machine, Rimek Minipress-I, India) using 12mm punches.

Evaluation of pre compression parameters [12]

Bulk Density

Both loose bulk density (LBD) and tapped bulk density (TBD) were determined. The loose bulk density is accurately weighted amount of sample (5 g) was transferred into a $25 \mathrm{ml}$ measuring cylinder carefully to read the unsettled apparent volume to the nearest graduated unit. The tapped bulk density is accurately weighted amount of sample (5 g) was transferred into a $25 \mathrm{ml}$ measuring cylinder. The measuring cylinder was then tapped 100 times on a plane hard wooden surface and measure the tapped volume to the nearest graduated unit. Calculate the loose bulk density and tapped bulk density in $\mathrm{g} / \mathrm{ml}$ by the following formula:

Loose bulk density (LBD) = Weight of granules / Apparent Volume

Tapped bulk density (TBD) = Weight of granules / Tapped volume

\section{Compressibility Index}

Percent compressibility of granules as determined by Carr's compressibility index is tapped bulk density minus loose bulk density divided by tapped bulk density.

\section{Hausner Ratio}

Hausner ratio is tapped bulk density divided by loose bulk density.

Table 2: Batch Codes for drugs and polymers

\begin{tabular}{cc}
\hline Drug and polymers & Batch Code \\
\hline Ciprofloxacin Hydrochloride & $\mathrm{C}$ \\
HPMC K100M & $\mathrm{H}$ \\
Ethyl Cellulose & $\mathrm{E}$ \\
HPMC K ${ }_{100} \mathrm{M}$ and Ethyl Cellulose combination & $\mathrm{HE}$ \\
\hline
\end{tabular}

Table 3: $3^{2}$ full factorial design for the preparations of batches of HPMC $K_{100} M$ and Ethyl Cellulose

\begin{tabular}{ccc}
\hline \multirow{2}{*}{ Formulation No } & \multicolumn{2}{c}{ Factors in Coded form } \\
\cline { 2 - 3 } & HPMC $\mathbf{K}_{\mathbf{1 0 0}} \mathbf{M}$ & Ethyl Cellulose \\
\hline $\mathrm{CHE}_{1}$ & 1 & 1 \\
$\mathrm{CHE}_{2}$ & -1 & 0 \\
$\mathrm{CHE}_{3}$ & 1 & -1 \\
$\mathrm{CHE}_{4}$ & 0 & -1 \\
$\mathrm{CHE}_{5}$ & -1 & -1 \\
$\mathrm{CHE}_{6}$ & -1 & -1 \\
$\mathrm{CHE}_{7}$ & 1 & 0 \\
$\mathrm{CHE}_{8}$ & 0 & 1 \\
$\mathrm{CHE}_{9}$ & 0 & 0 \\
\hline
\end{tabular}

Table 4: Factors used and coded level for $3^{2}$ full factorial designs

\begin{tabular}{cccc}
\hline \multirow{2}{*}{ Factors used } & \multicolumn{3}{c}{ Coded Level } \\
\cline { 2 - 4 } & $\mathbf{- 1}$ & $\mathbf{0}$ & $\mathbf{+ 1}$ \\
\hline HPMC K ${ }_{100} \mathrm{M}(\mathrm{mg})$ & 40 & 60 & 80 \\
Ethyl Cellulose $(\mathrm{mg})$ & 15 & 30 & 45 \\
\hline
\end{tabular}


Angle of Repose $(\theta)$

The frictional forces in a loose powder or granules can be measured by angle of repose. This is the maximum angle possible between the surface of a pile of powder or granules and the horizontal plane. A funnel was kept vertically in a stand at a specified height above a paper placed on a horizontal surface. The funnel bottom is closed and 10 grams of sample powder is filled in funnel. Then funnel was opened to release the powder on the paper to form a smooth conical heap, is found by measuring in different direction. The height of the heap was measured by using scale. The value of angle of repose are calculated by using the following formula, $\tan \theta=h / r$

\section{Where}

$$
\theta=\tan ^{-1}(\mathrm{~h} / \mathrm{r})
$$

$\theta=$ Angle of repose, $h=$ Height of the heap and $r=$ Radius of the heap

\section{Post Compression Parameters [13-14]}

Tablet Dimension

Thickness and diameter were measured using a calibrated screw gauge. Three tablets of each formulation were picked randomly and thickness was measured individually.

\section{Hardness}

Hardness indicates the ability of a tablet to withstand mechanical shocks while handling the hardness of the tablets was determined using Monsanto hardness tester. It is expressed in $\mathrm{Kg} / \mathrm{cm}^{2}$. Three tablets were randomly selected and hardness of the tablets was determined.

\section{Friability Test}

The friability of tablets was determined using Roche friabilator. It is expressed in percentage (\%). Ten tablets were initially weighed $\left(\mathrm{W}_{\text {initial }}\right)$ and transferred into friabilator. The friabilator was operated $25 \mathrm{rpm}$ for 4 minutes or run up to 100 revolutions. The tablets were weighed again $\left(\mathrm{W}_{\text {final }}\right)$. The percentage friability was then calculated.

\section{Uniformity in Weight}

Twenty tablets were selected randomly from each batch and weighed. Weight of each tablet was recorded with the help of digital balance. The readings were recorded and tabulated.

\section{In vitro Buoyancy Studies}

The time between introduction of dosage forms and its buoyancy in the simulated gastric fluid and the time during which the dosage form remain buoyant were measured. The time taken for dosage form to emerge on surface of medium called total lag time (TLT) or buoyancy lag time (BLT) and the total duration of time by which dosage form remain buoyant is called total floating time.

\section{In-vitro Drug Release Studies}

Three tablets of each formulation were used in the release experiment. In-vitro drug release of tablets was studied using USP type II apparatus at $37 \pm 0.5^{\circ} \mathrm{C}$ in 900 $\mathrm{ml} 0.1 \mathrm{~N} \mathrm{HCl}$ solution $(\mathrm{pH} ; 1.2)$ with a speed of $50 \mathrm{rpm}$. At appropriate time intervals $5 \mathrm{ml}$ of sample was withdrawn and an equal volume of medium was added to maintain the volume constant. Samples were analyzed by using UV- Visible Spectrophotometer at $276 \mathrm{~nm}$. The dissolution data obtained were plotted as percent cumulative drug release versus time.

\begin{tabular}{|c|c|c|c|c|c|c|c|c|c|c|}
\hline $\begin{array}{l}\text { S. } \\
\text { N } \\
\text { o. }\end{array}$ & $\begin{array}{l}\text { Ingredie } \\
\text { nts (mg) }\end{array}$ & $\begin{array}{l}\mathrm{CH} \\
\mathrm{E}_{1}\end{array}$ & $\begin{array}{c}\mathrm{CH} \\
\mathrm{E}_{2}\end{array}$ & $\begin{array}{c}\mathrm{CH} \\
\mathrm{E}_{3}\end{array}$ & $\begin{array}{c}\mathrm{CH} \\
\mathrm{E}_{4}\end{array}$ & $\begin{array}{c}\mathrm{CH} \\
\mathrm{E}_{5}\end{array}$ & $\begin{array}{l}\mathrm{CH} \\
\mathrm{E}_{6}\end{array}$ & $\begin{array}{l}\mathrm{CH} \\
\mathrm{E}_{7}\end{array}$ & $\begin{array}{l}\mathrm{CH} \\
\mathrm{E}_{8}\end{array}$ & $\begin{array}{c}\mathrm{CH} \\
\mathrm{E}_{9}\end{array}$ \\
\hline 1 & $\begin{array}{c}\text { Ciproflo } \\
\text { xacin } \\
\mathrm{HCl}\end{array}$ & 250 & 250 & 250 & 250 & 250 & 250 & 250 & 250 & 250 \\
\hline 2 & $\begin{array}{l}\text { HPMC } \\
\mathrm{K}_{100} \mathrm{M}\end{array}$ & 80 & 40 & 80 & 60 & 40 & 40 & 80 & 60 & 60 \\
\hline 3 & $\begin{array}{l}\text { Ethyl } \\
\text { cellulose } \\
\text { Sod. }\end{array}$ & 45 & 30 & 15 & 15 & 45 & 15 & 30 & 45 & 30 \\
\hline 4 & $\begin{array}{l}\text { bicarbon } \\
\text { ate }\end{array}$ & 100 & 100 & 100 & 100 & 100 & 100 & 100 & 100 & 100 \\
\hline 5 & MCC & 15 & 70 & 45 & 65 & 55 & 85 & 30 & 35 & 50 \\
\hline 6 & Talc & 5 & 5 & 5 & 5 & 5 & 5 & 5 & 5 & 5 \\
\hline 7 & $\begin{array}{c}\text { Mg. } \\
\text { stearate }\end{array}$ & 5 & 5 & 5 & 5 & 5 & 5 & 5 & 5 & 5 \\
\hline \multicolumn{2}{|c|}{$\begin{array}{l}\text { Total Tablet } \\
\text { Weight }(\mathrm{mg})\end{array}$} & 500 & 500 & 500 & 500 & 500 & 500 & 500 & 500 & 500 \\
\hline
\end{tabular}

\section{RESULTS AND DISCUSSION}

\section{Identification of drugs}

The received gift samples of Ciprofloxacin were characterized by Infrared (IR) Spectroscopy, melting point determination and ultraviolet (UV) spectroscopy. Infrared (IR) spectra

The IR spectra of the drugs were recorded by using FTIR (DRS) technique. The spectrum showed peaks corresponding to the functional groups present in the drug structure.

Melting point

The melting point of the drug sample Ciprofloxacin was found to be $147^{\circ} \mathrm{C}$ and $190^{\circ} \mathrm{C}$ respectively that comply with the reference data.

\section{Ultraviolet (UV) spectroscopy}

In UV scanning from standard solutions of Ciprofloxacin, the wavelength of maximum absorption $\left(\lambda_{\max }\right)$ was determined at $0.1 \mathrm{~N} \mathrm{HCl}$. It was found to be $276 \mathrm{~nm}$ in $0.1 \mathrm{~N} \mathrm{HCl}$ for Ciprofloxacin which are similar to the values given in literature.

\section{Drug-polymer compatibility study}

Interaction between the drug and added excipients plays a vital role in establishing stability of the formulation. Hence, the drug-excipient compatibility study is highly desirable before developing any formulation. Interaction between drug and excipient can occur by means of several mechanisms like adsorption, complexation, chemical interaction, $\mathrm{pH}$ effect, eutectic formation resulting in drug products with desired or undesired properties.

\section{Fourier-Transform Infrared Spectroscopy}

Fourier-transform infrared (DRS) spectra were obtained by using an FT IR-Affinity-1 spectrophotometer (DRS8000) SHIMADZU, Japan. The drug sample (Ciprofloxacin) was previously ground and mixed thoroughly with potassium bromide, an infrared transparent matrix, at 1:1 (Sample: $\mathrm{KBr}$ ) ratio, respectively. The $\mathrm{KBr}$ powder was used as blank for 
Gourishyam Pasa et al. / Formulation Design and Optimization of Floating Matrix Tablets of Ciprofloxacin.......

background correction in FT-IR studies. Forty five scans were obtained at a resolution of $4 \mathrm{~cm}^{-1}$ from 4000 to $400 \mathrm{~cm}^{-1}$.

[̈) SHIMADZU

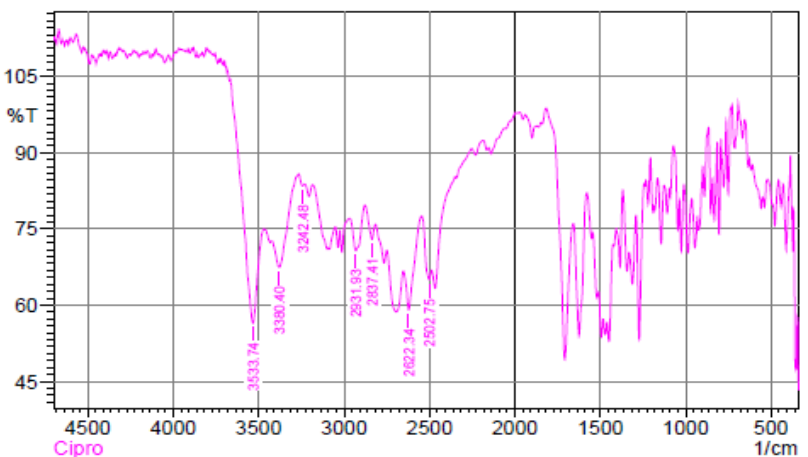

Fig. 1: FTIR Spectra of Ciprofloxacin $\mathrm{HCl}$

ФSHIMADZU

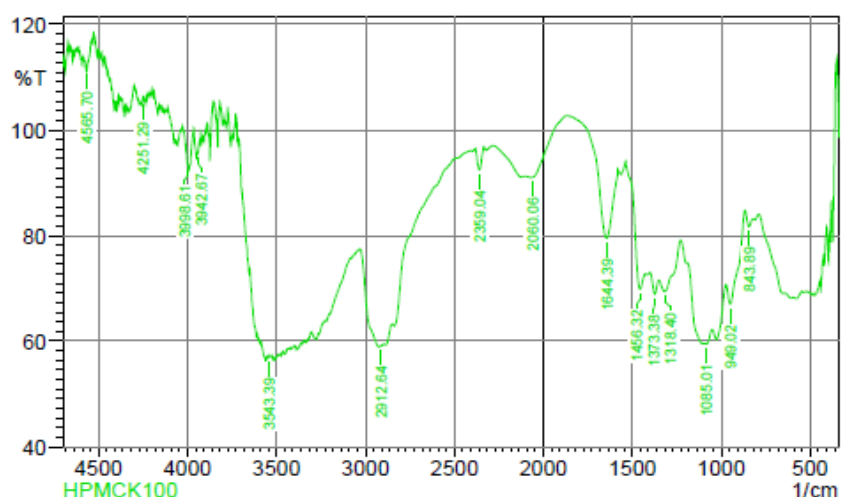

Fig. 2: FTIR Spectra of HPMC $K_{100} M$

ФSHIMADZU

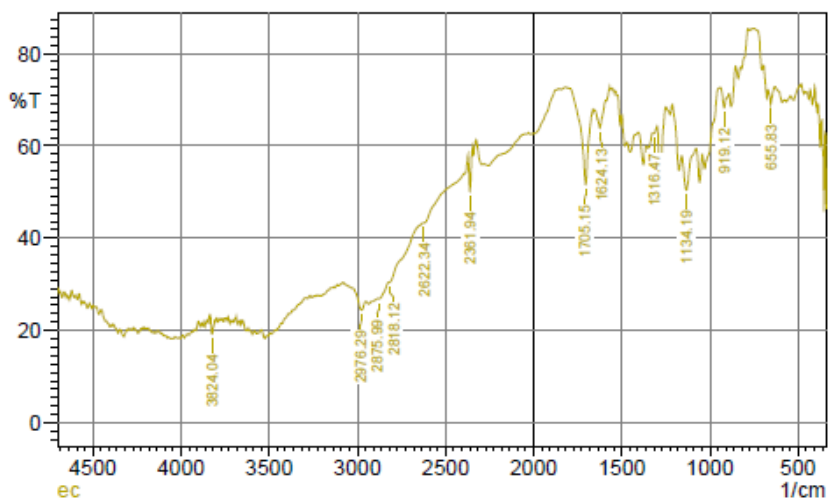

Fig. 3: FTIR Spectra of Ethyl Cellulose

ФSHIMADZU

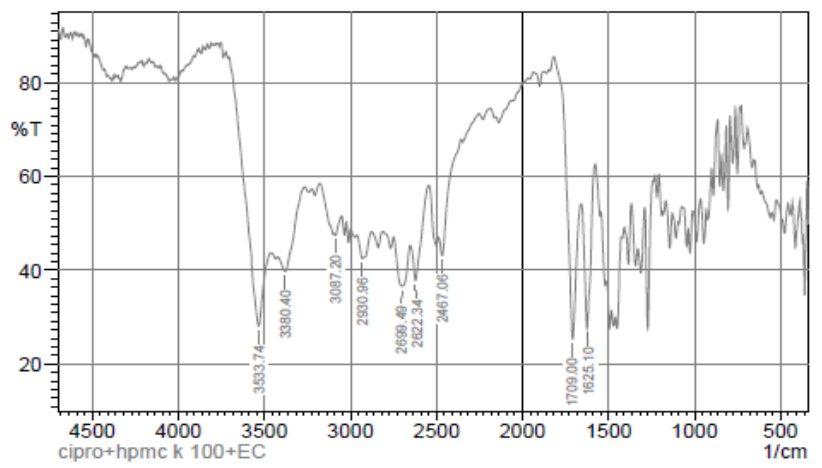

Fig. 4: FTIR Spectra of Ciprofloxacin with HPMC $\mathrm{K}_{100} \mathrm{M}$ and Ethyl Cellulose

\section{Differential Scanning Calorimetry}

The interactions between drugs and a distinct mixture [1:1] were then investigated by DSC. Interactions in the sample are derived or deduced from DSC by changes in the thermal events, such as elimination of an endothermic or exothermic peak, or appearance of a new peak. However, some broadening of peaks leading to changes in the area, onset of peak, and changes in peak temperature occur simply due to mixing of the components without indicating any significant interaction.

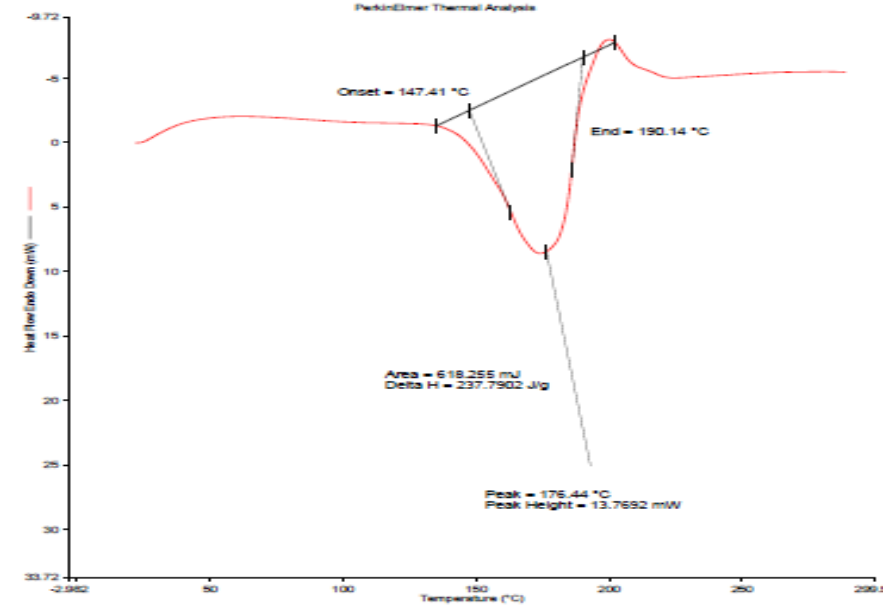

Fig. 5: DSC thermogram of Ciprofloxacin $\mathrm{HCl}$

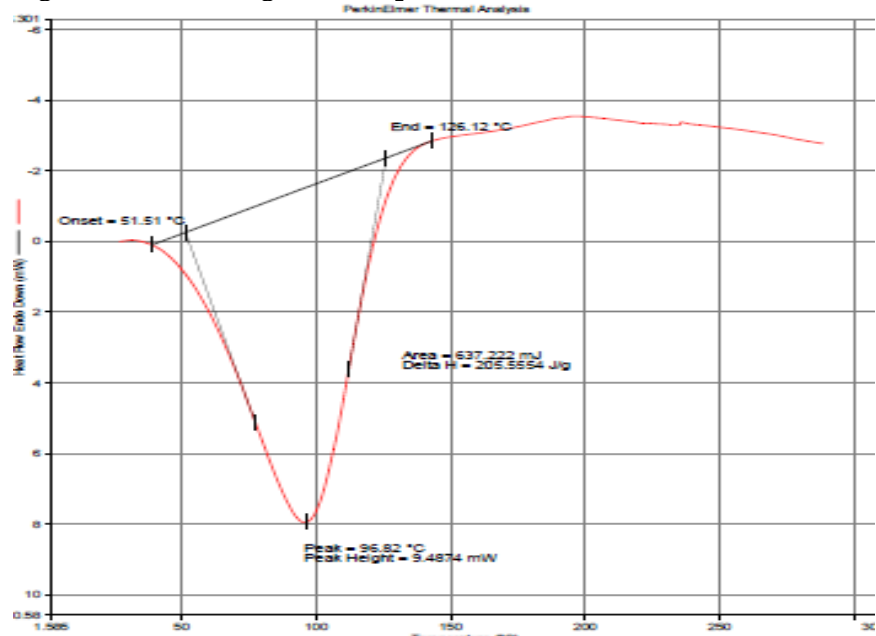

Fig. 6: DSC thermogram of HPMC K100 M

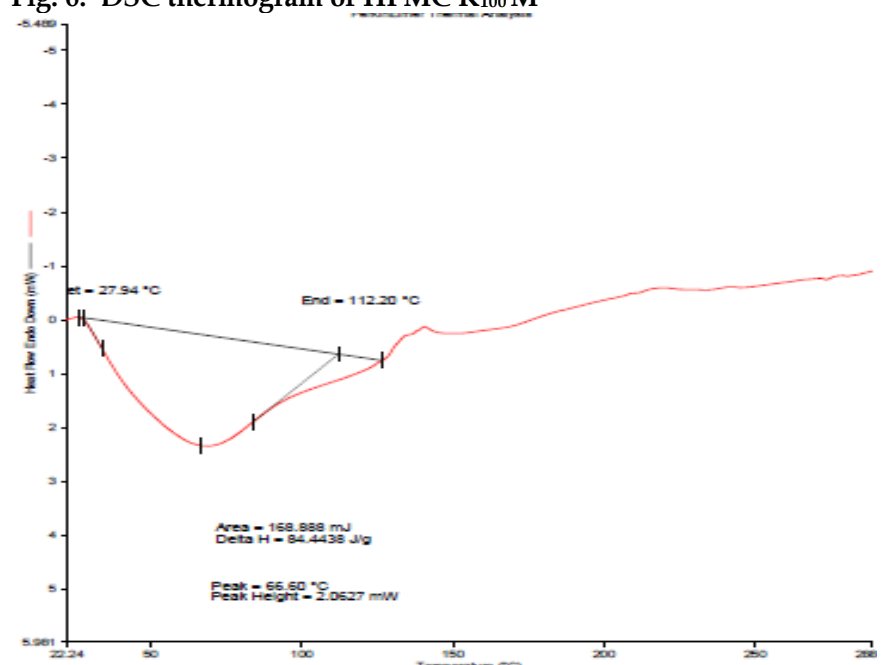

Fig. 7: DSC thermogram of Ethyl Cellulose 
Gourishyam Pasa et al. / Formulation Design and Optimization of Floating Matrix Tablets of Ciprofloxacin.......

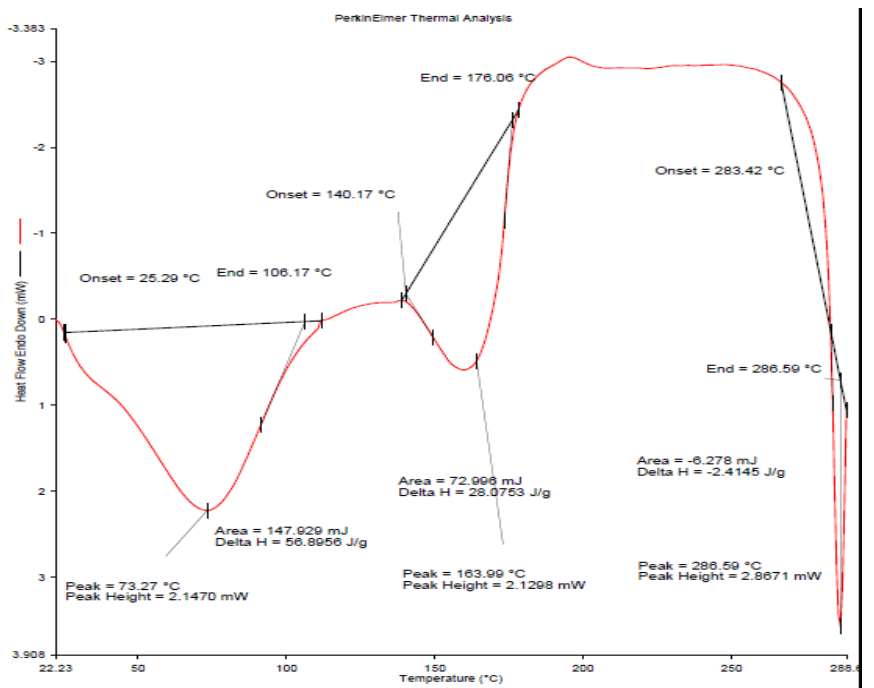

Fig. 8: DSC thermogram of Ciprofloxacin with HPMC $\mathrm{K}_{100} \mathrm{M}$ and Ethyl Cellulose

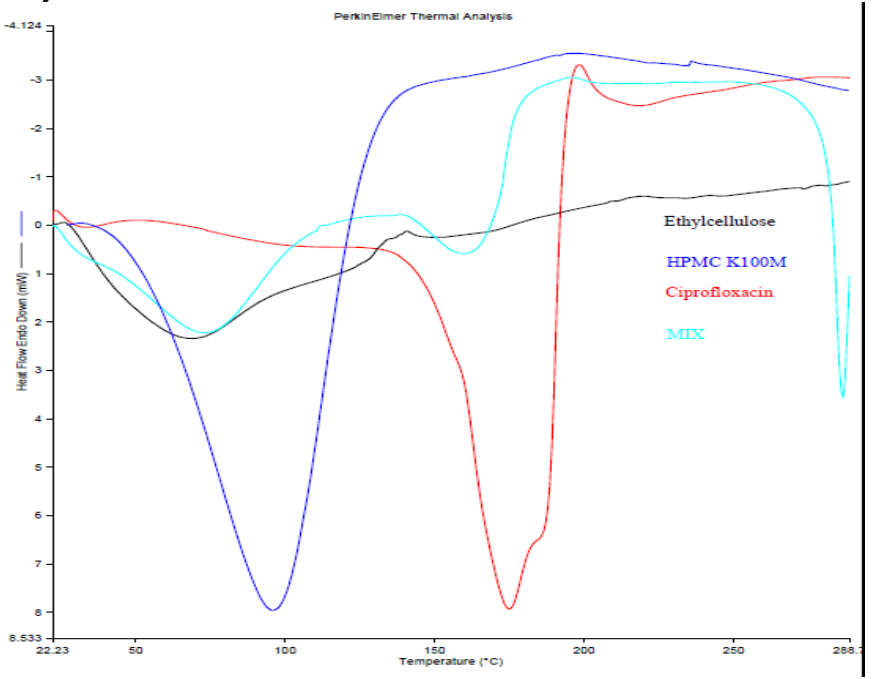

Fig. 9: DSC thermogram of Overlay spectra of HPMC $K_{100}$ Ciprofloxacin, Ethyl Cellulose and Mixture

\section{Analytical method development}

UV-Vis Spectrophotometric Method Development for Ciprofloxacin $\mathrm{HCl}$

Serial dilution of Ciprofloxacin was prepared in $0.1 \mathrm{~N}$ $\mathrm{HCl}$ from $2 \mu \mathrm{g} / \mathrm{mL}$ to $10 \mu \mathrm{g} / \mathrm{mL}$ and scanned for absorption maxima $\left(\lambda_{\text {max. }}\right)$ in the range of 200 to $400 \mathrm{~nm}$.

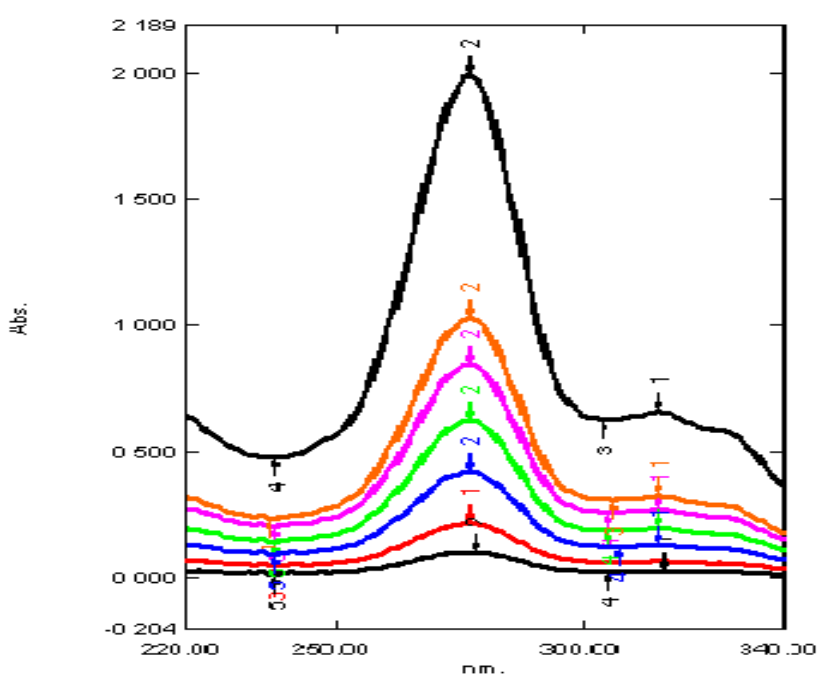

Fig. 10: Overlay Spectra of Ciprofloxacin in $0.1 \mathrm{~N} \mathrm{HCl}$

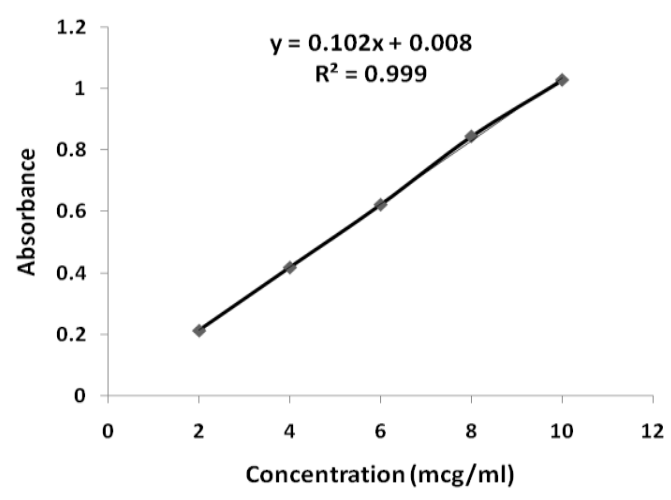

Fig. 11: Calibration Curve of Ciprofloxacin $\mathrm{HCl}$ in $0.1 \mathrm{~N} \mathrm{HCl}$

Formulation development and evaluation of Ciprofloxacin floating tablets

Table 6: Physical Parameters of Ciprofloxacin Tablet formulations $\mathrm{CHE}_{1}$ to $\mathrm{CHE}_{9}$

\begin{tabular}{|c|c|c|c|c|c|c|c|c|c|}
\hline Blend & & & & & atch & & & & \\
\hline $\begin{array}{c}\text { Paramet } \\
\text { ers }\end{array}$ & $\begin{array}{l}\mathrm{CH} \\
\mathrm{E}_{1}\end{array}$ & $\begin{array}{c}\mathrm{CH} \\
\mathrm{E}_{2}\end{array}$ & $\begin{array}{c}\mathrm{CH} \\
\mathrm{E}_{3}\end{array}$ & $\begin{array}{c}\mathrm{CH} \\
\mathrm{E}_{4}\end{array}$ & $\begin{array}{c}\mathrm{CH} \\
\mathrm{E}_{5} \\
\end{array}$ & $\begin{array}{c}\mathrm{CH} \\
\mathrm{E}_{6}\end{array}$ & $\begin{array}{c}\mathrm{CH} \\
\mathrm{E}_{7}\end{array}$ & $\begin{array}{c}\mathrm{CH} \\
\mathrm{E}_{8}\end{array}$ & $\begin{array}{c}\mathrm{CH} \\
\mathrm{E} 9 \\
\end{array}$ \\
\hline & 0.48 & 0.57 & 0.60 & 0.58 & 0.5 & 0.53 & 0.51 & 0.45 & 0.47 \\
\hline $\begin{array}{l}\text { Density } \\
(\mathrm{gm} / \mathrm{ml})\end{array}$ & 9 & 1 & 6 & 2 & 02 & 2 & 0 & 4 & 1 \\
\hline $\begin{array}{l}\text { Tapped } \\
\text { Density } \\
(\mathrm{gm} / \mathrm{ml}) \\
\text { Carr's }\end{array}$ & $\begin{array}{c}0.55 \\
3\end{array}$ & 1.16 & $\begin{array}{c}1.15 \\
1\end{array}$ & $\begin{array}{c}1.12 \\
3\end{array}$ & $\begin{array}{l}0.5 \\
72\end{array}$ & $\begin{array}{c}0.61 \\
4\end{array}$ & $\begin{array}{c}0.58 \\
0\end{array}$ & $\begin{array}{c}0.61 \\
4\end{array}$ & $\begin{array}{c}0.62 \\
4\end{array}$ \\
\hline $\begin{array}{c}\text { Compre } \\
\text { ssibility } \\
(\%)\end{array}$ & 17.9 & $\begin{array}{c}0.50 \\
3\end{array}$ & $\begin{array}{c}0.53 \\
3\end{array}$ & $\begin{array}{c}0.51 \\
3\end{array}$ & $\begin{array}{l}12 . \\
33\end{array}$ & $\begin{array}{c}13.3 \\
1\end{array}$ & 11.9 & $\begin{array}{c}25.5 \\
5\end{array}$ & $\begin{array}{c}22.5 \\
4\end{array}$ \\
\hline $\begin{array}{l}\text { Hausner } \\
\text { 's Ratio } \\
\text { Tablet } \\
\text { Paramet } \\
\text { ers }\end{array}$ & 1.23 & $\begin{array}{c}0.62 \\
6\end{array}$ & $\begin{array}{c}0.57 \\
9\end{array}$ & $\begin{array}{c}0.61 \\
4\end{array}$ & $\begin{array}{c}1.1 \\
5\end{array}$ & $\begin{array}{c}1.14 \\
3\end{array}$ & $\begin{array}{c}1.12 \\
3\end{array}$ & $\begin{array}{c}1.33 \\
6\end{array}$ & $\begin{array}{c}1.28 \\
9\end{array}$ \\
\hline $\begin{array}{l}\text { Weight } \\
\text { Variatio } \\
\text { n (mg) }\end{array}$ & $\begin{array}{c}503 \\
\pm \\
5.3\end{array}$ & $\begin{array}{c}508 \\
\pm \\
5.3\end{array}$ & $\begin{array}{c}503 \\
\pm \\
5.27\end{array}$ & $\begin{array}{c}490 \\
\pm \\
5.22\end{array}$ & $\begin{array}{c}499 \\
\pm \\
5.2 \\
3\end{array}$ & $\begin{array}{c}506 \\
\pm \\
5.27\end{array}$ & $\begin{array}{c}502 \\
\pm \\
5.22\end{array}$ & $\begin{array}{c}501 \\
\pm \\
5.23\end{array}$ & $\begin{array}{c}494 \\
\pm \\
5.32\end{array}$ \\
\hline $\begin{array}{l}\text { Hardnes } \\
\mathrm{s} \\
\left(\mathrm{kg} / \mathrm{cm}^{2}\right.\end{array}$ & $\begin{array}{l}5.8 \pm \\
0.53\end{array}$ & $\begin{array}{l}5.8 \pm \\
0.25\end{array}$ & $\begin{array}{l}5.8 \pm \\
0.31\end{array}$ & $\begin{array}{l}5.8 \pm \\
0.25\end{array}$ & $\begin{array}{c}6.4 \\
\pm 0 . \\
6\end{array}$ & $\begin{array}{l}6.1 \pm \\
0.71\end{array}$ & $\begin{array}{l}5.7 \pm \\
0.52\end{array}$ & $\begin{array}{l}5.5 \pm \\
0.54\end{array}$ & $\begin{array}{l}6.3 \pm \\
0.54\end{array}$ \\
\hline $\begin{array}{c}\text { Friabilit } \\
\mathrm{y}(\%)\end{array}$ & 0.61 & 0.68 & 0.79 & 0.52 & $\begin{array}{c}0.6 \\
6\end{array}$ & 0.48 & 0.53 & 0.58 & 0.60 \\
\hline $\begin{array}{c}\text { Drug } \\
\text { Content }\end{array}$ & $\begin{array}{c}99.7 \\
2\end{array}$ & 98.2 & $\begin{array}{c}96.5 \\
3\end{array}$ & $\begin{array}{c}98.5 \\
3\end{array}$ & 94 & $\begin{array}{c}97.5 \\
6\end{array}$ & 98.2 & $\begin{array}{c}99.4 \\
3\end{array}$ & $\begin{array}{c}98.5 \\
3\end{array}$ \\
\hline
\end{tabular}

Table 7: Kinetic Analysis of Dissolution profile of Ciprofloxacin from $\mathrm{CHE}_{1}$

\begin{tabular}{|c|c|c|c|c|c|c|c|c|c|c|}
\hline \multicolumn{2}{|c|}{ Models } & $\begin{array}{c}\mathrm{CH} \\
\mathrm{E}_{1}\end{array}$ & $\begin{array}{c}\mathrm{CH} \\
\mathrm{E}_{2}\end{array}$ & $\begin{array}{c}\mathrm{CH} \\
\mathrm{E}_{3}\end{array}$ & $\begin{array}{c}\mathrm{CH} \\
\mathrm{E}_{4}\end{array}$ & $\begin{array}{c}\mathrm{CH} \\
\mathrm{E}_{5}\end{array}$ & $\begin{array}{c}\mathrm{CH} \\
\mathrm{E}_{6}\end{array}$ & $\begin{array}{c}\mathrm{CH} \\
\mathrm{E}_{7}\end{array}$ & $\begin{array}{c}\mathrm{CH} \\
\mathrm{E}_{8}\end{array}$ & $\begin{array}{c}\mathrm{CH} \\
\mathrm{E}_{9}\end{array}$ \\
\hline \multirow{3}{*}{$\begin{array}{c}\text { Pepp } \\
\text { as }\end{array}$} & & 0.70 & 0.45 & 0.48 & 0.55 & 0.50 & 0.36 & 0.54 & 0.66 & 0.65 \\
\hline & $\mathbf{n}$ & 5 & 0 & 7 & 1 & 9 & 8 & 7 & 5 & 7 \\
\hline & $\mathbf{R}$ & 0.99 & 0.98 & 0.94 & 0.98 & 0.99 & 0.93 & 0.98 & 0.99 & 0.98 \\
\hline Mode & 2 & 7 & 9 & 0 & 6 & 2 & 6 & 3 & 5 & 9 \\
\hline \multirow[t]{2}{*}{1} & K & 11.3 & 33.2 & 21.8 & 24.4 & 27.2 & 41.9 & 17.1 & 15.8 & 18.7 \\
\hline & p & 2 & 1 & 2 & 3 & 2 & 7 & 7 & 1 & 4 \\
\hline \multirow{2}{*}{$\begin{array}{l}\text { Higu } \\
\text { chi }\end{array}$} & $\mathbf{R}$ & 0.96 & 0.98 & 0.97 & 0.98 & 0.99 & 0.83 & 0.98 & 0.98 & 0.95 \\
\hline & 2 & 6 & 4 & 2 & 7 & 6 & 9 & 0 & 0 & 4 \\
\hline \multirow{2}{*}{$\begin{array}{c}\text { Mode } \\
1\end{array}$} & K & 17.2 & 30 & 21.6 & 27.3 & 27.8 & 321 & 19.1 & 22.0 & 26.1 \\
\hline & h & 4 & 30 & 2 & 5 & 3 & 32.1 & 4 & 8 & 2 \\
\hline \multirow{4}{*}{$\begin{array}{l}\text { Zero- } \\
\text { Orde }\end{array}$} & $\mathbf{R}$ & 0.92 & 0.62 & 0.84 & 0.84 & 0.77 & 0.27 & 0.87 & 0.88 & 0.93 \\
\hline & 2 & 4 & 1 & 7 & 3 & 4 & 1 & 7 & 7 & 8 \\
\hline & K & 5.94 & 10.1 & 7.41 & 9.33 & 9.46 & 10.6 & 6.56 & 7.58 & 9.03 \\
\hline & 0 & 9 & 1 & 0 & 5 & 7 & 7 & 9 & 1 & 0 \\
\hline \multirow{4}{*}{$\begin{array}{l}\text { First- } \\
\text { Orde } \\
\text { r }\end{array}$} & $\mathbf{R}$ & 0.99 & 0.96 & 0.96 & 0.94 & 0.96 & 0.82 & 0.98 & 0.99 & 0.90 \\
\hline & 2 & 7 & 8 & 1 & 4 & 5 & 1 & 6 & 4 & 1 \\
\hline & K & 0.08 & 0.27 & 0.11 & 0.24 & 0.23 & 0.24 & 0.09 & 0.12 & 0.26 \\
\hline & 1 & 0 & 1 & 9 & 8 & 5 & 2 & 2 & 5 & 8 \\
\hline
\end{tabular}


Gourishyam Pasa et al. / Formulation Design and Optimization of Floating Matrix Tablets of Ciprofloxacin.......

Table 8: Factorial design of various polymer concentrations of HPMC $\mathrm{K}_{100}$ and Ethyl Cellulose

\begin{tabular}{|c|c|c|c|c|c|c|c|}
\hline Std & $\begin{array}{c}\mathrm{Ru} \\
\mathrm{n}\end{array}$ & Block & $\begin{array}{c}\text { Factor } \\
1 \text { A:X1 } \\
\text { HPM } \\
\text { C } \\
\text { K100 } \\
\text { mg }\end{array}$ & $\begin{array}{c}\text { Factor } \\
2 \text { B:X2 } \\
\text { EC } \\
\mathrm{mg}\end{array}$ & $\begin{array}{c}\text { Respons } \\
\text { e } 1 \text { Y1 } \\
\%\end{array}$ & $\begin{array}{c}\text { Respons } \\
\text { e } 2 \text { Y } 6 \\
\%\end{array}$ & $\begin{array}{c}\text { Respons } \\
\text { e } 3 \text { Y12 } \\
\%\end{array}$ \\
\hline 4 & 1 & $\begin{array}{c}\text { Block } \\
1\end{array}$ & 80.00 & 45.00 & 11 & 42 & 64 \\
\hline 5 & 2 & $\begin{array}{c}\text { Block } \\
1\end{array}$ & 40.00 & 30.00 & 34 & 76 & 95 \\
\hline 2 & 3 & $\begin{array}{c}\text { Block } \\
1\end{array}$ & 80.00 & 15.00 & 26 & 49 & 80 \\
\hline 7 & 4 & $\begin{array}{c}\text { Block } \\
1\end{array}$ & 60.00 & 15.00 & 27 & 67 & 94 \\
\hline 3 & 5 & $\begin{array}{c}\text { Block } \\
1\end{array}$ & 40.00 & 45.00 & 29 & 68 & 94 \\
\hline 1 & 6 & $\begin{array}{c}\text { Block } \\
1\end{array}$ & 40.00 & 15.00 & 41 & 90 & 94 \\
\hline 6 & 7 & $\begin{array}{c}\text { Block } \\
1\end{array}$ & 80.00 & 30.00 & 19 & 44 & 71 \\
\hline 8 & 8 & $\begin{array}{c}\text { Block } \\
1\end{array}$ & 60.00 & 45.00 & 15 & 53 & 80 \\
\hline 9 & 9 & $\begin{array}{c}\text { Block } \\
1\end{array}$ & 60.00 & 30.00 & 21 & 60 & 97 \\
\hline
\end{tabular}

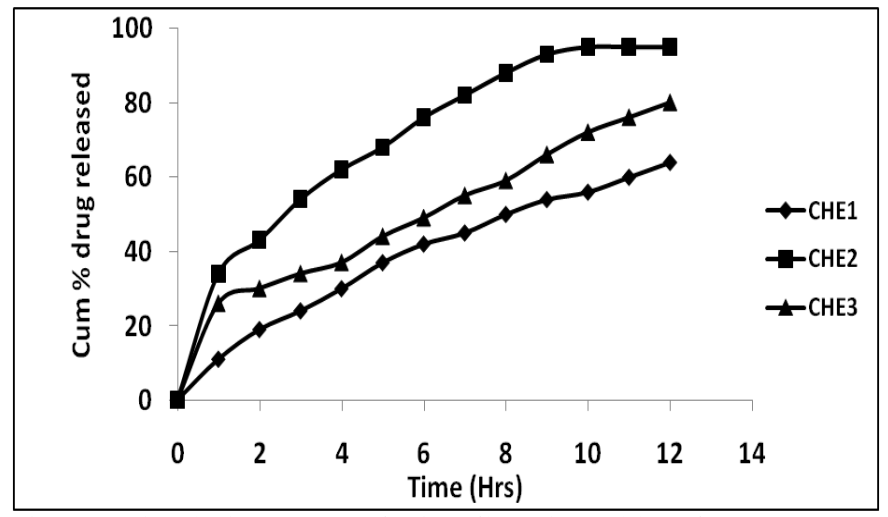

Fig. 12: Dissolution curve of Ciprofloxacin Tablets from $\mathrm{CHE}_{1}$ to $\mathrm{CHE}_{3}$

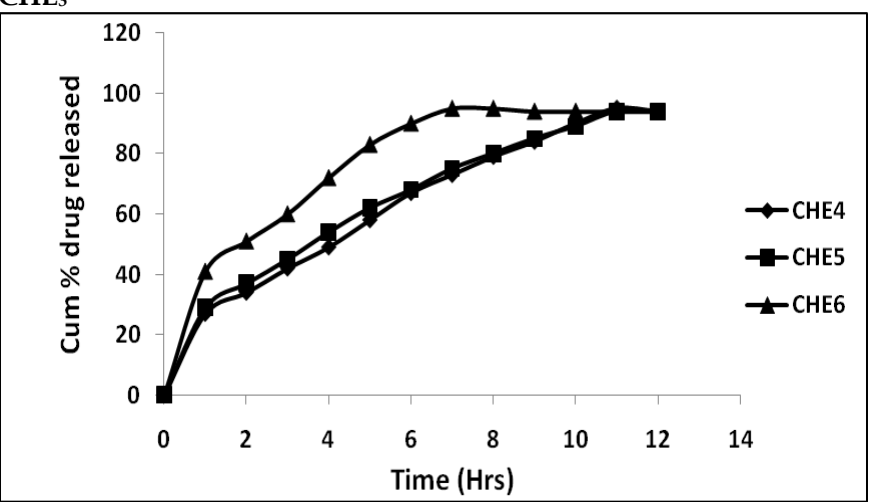

Fig. 13: Dissolution curve of Ciprofloxacin Tablets from $\mathrm{CHE}_{4}$ to $\mathrm{CHE}_{6}$

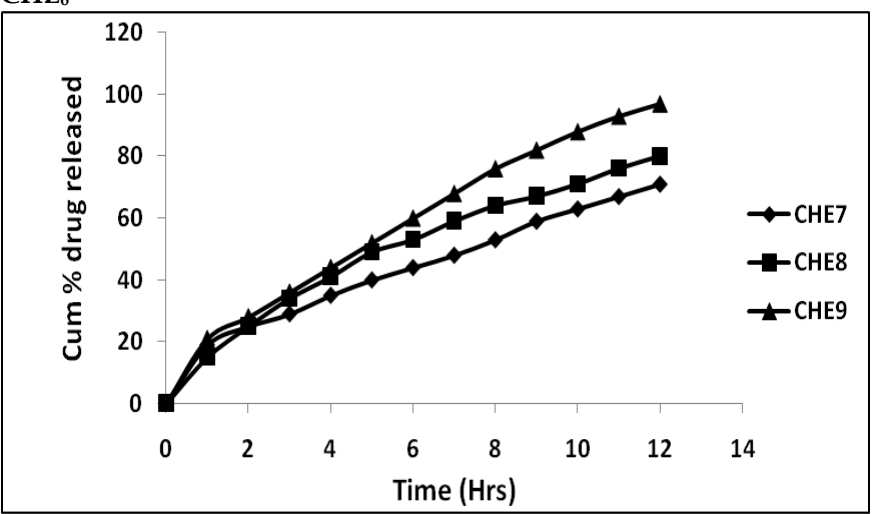

Fig. 14: Dissolution curve of Ciprofloxacin Tablets from $\mathrm{CHE}_{7}$ to CHE9
Anova for Response surface cubic model of HPMC $K_{100}$ and Ethyl Cellulose

\begin{tabular}{|c|c|c|c|c|c|c|}
\hline Response: $\quad$ Y1 & & & & & & \\
\hline \multicolumn{7}{|c|}{ ANOVA for Response Surface Reduced Cubic Model } \\
\hline \multicolumn{7}{|c|}{ Analysis of variance table [Partial sum of squares] } \\
\hline & Sum of & & Mean & $\mathbf{F}$ & & \\
\hline Source & Squares & DF & Square & Value & Prob $>F$ & \\
\hline Model & 705.53 & 7 & 100.79 & 3628.43 & 0.0128 & \\
\hline$A$ & 112.50 & 1 & 112.50 & 4050.00 & 0.0100 & \\
\hline$B$ & 72.00 & 1 & 72.00 & 2592.00 & 0.0125 & \\
\hline$A^{2}$ & 64.22 & 1 & 64.22 & 2312.00 & 0.0132 & \\
\hline$B^{2}$ & 0.056 & 1 & 0.056 & 2.00 & 0.3918 & \\
\hline$A B$ & 2.25 & 1 & 2.25 & 81.00 & 0.0704 & \\
\hline$A^{2} B$ & 0.75 & 1 & 0.75 & 27.00 & 0.1210 & \\
\hline$A B^{2}$ & 0.75 & 1 & 0.75 & 27.00 & 0.1210 & \\
\hline Residual & 0.028 & 1 & 0.028 & & & \\
\hline Cor Total & 705.56 & 8 & & & & \\
\hline Std. Dev. & 0.17 & \multicolumn{2}{|c|}{ R-Squared } & 1.0000 & & \\
\hline Mean & 24.78 & \multicolumn{2}{|c|}{ Adj R-Squarec } & 0.9997 & & \\
\hline C.V. & 0.67 & \multicolumn{2}{|c|}{ Pred R-Square } & 0.9928 & & \\
\hline \multirow[t]{2}{*}{ PRESS } & 5.06 & \multicolumn{2}{|c|}{ Adeq Precisior } & 190.919 & & \\
\hline & Coefficient & & Standard & $95 \% \mathrm{Cl}$ & $95 \% \mathrm{Cl}$ & \\
\hline Factor & Estimate & $\mathrm{DF}$ & Error & Low & High & VIF \\
\hline Intercept & 20.89 & 1 & 0.12 & 19.31 & 22.47 & \\
\hline A-X1 HPMCK100 & -7.50 & 1 & 0.12 & -9.00 & -6.00 & 3.00 \\
\hline $\mathrm{B}-\mathrm{X} 2 \mathrm{EC}$ & -6.00 & 1 & 0.12 & -7.50 & -4.50 & 3.00 \\
\hline$A^{2}$ & 5.67 & 1 & 0.12 & 4.17 & 7.16 & 1.00 \\
\hline B2 & 0.17 & 1 & 0.12 & -1.33 & 1.66 & 1.00 \\
\hline$A B$ & -0.75 & 1 & 0.083 & -1.81 & 0.31 & 1.00 \\
\hline$A^{2} B$ & -0.75 & 1 & 0.14 & -2.58 & 1.08 & 3.00 \\
\hline$A B^{2}$ & -0.75 & 1 & 0.14 & -2.58 & 1.08 & 3.00 \\
\hline
\end{tabular}

Final Equation in Terms of Coded Factors:

$$
\begin{gathered}
\mathrm{Y} 1= \\
+20.89 \\
-7.50 \text { * } \mathrm{A} \\
-6.00{ }^{*} \mathrm{~B} \\
+5.67{ }^{*} \mathrm{~A} 2 \\
+0.17 \text { * } \mathrm{B} 2 \\
-0.75{ }^{*} \mathrm{~A} \text { * } \mathrm{B} \\
-0.75{ }^{*} \mathrm{~A} 2{ }^{*} \mathrm{~B}
\end{gathered}
$$

DESIGN-EXPERT Plot

$Y 1$

$X=A: X 1$ HPMCK100

$Y=B: X 2 E C$

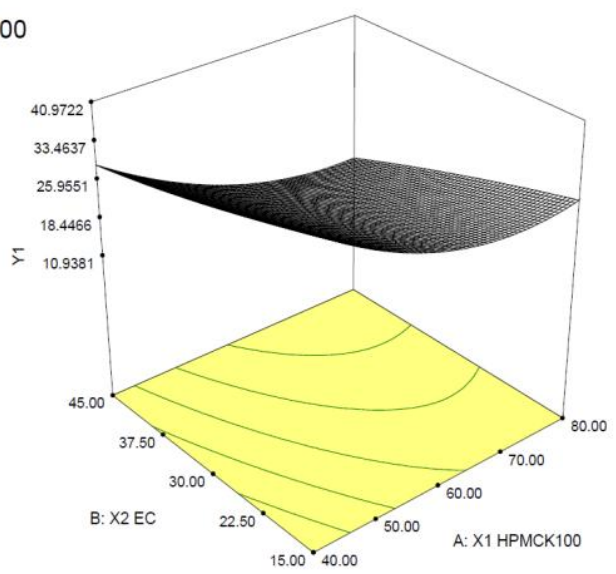

Fig. 15: Surface design of response Y1\% by varying quantities of HPMC $\mathrm{K}_{100} \mathrm{M}$ and Ethyl Cellulose 


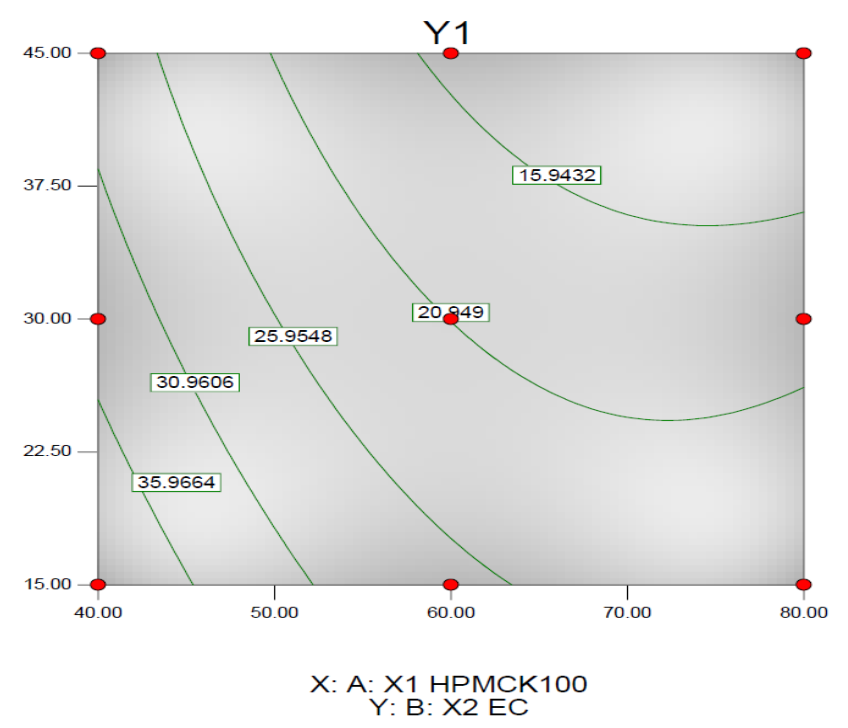

Fig. 16: Related contour plot indicating various levels of HPMC $\mathrm{K}_{100 \mathrm{M}}$ and Ethyl Cellulose DESIGN-EXPERT Plat

Y6

$X=A: X 1$ HPMCK 100 $Y=B: X 2 E C$

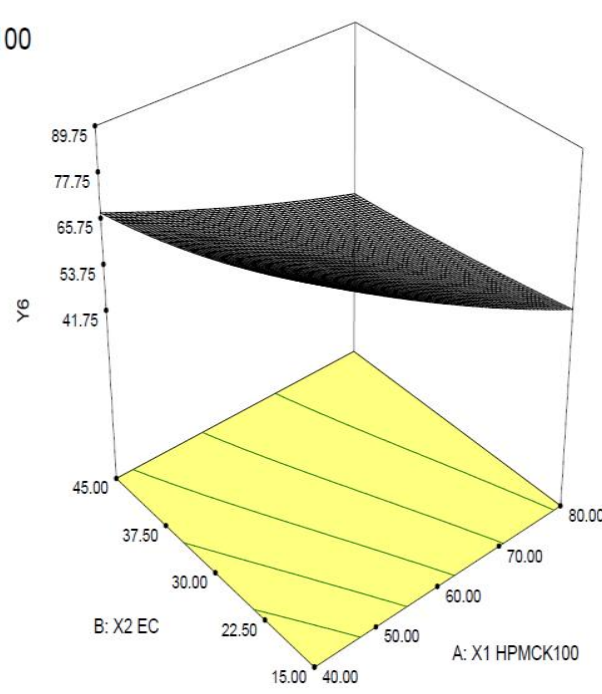

Fig. 17: Surface design of response $\mathrm{Y} 6 \%$ by varying quantities of HPMC $K_{100} M$ and Ethyl Cellulose

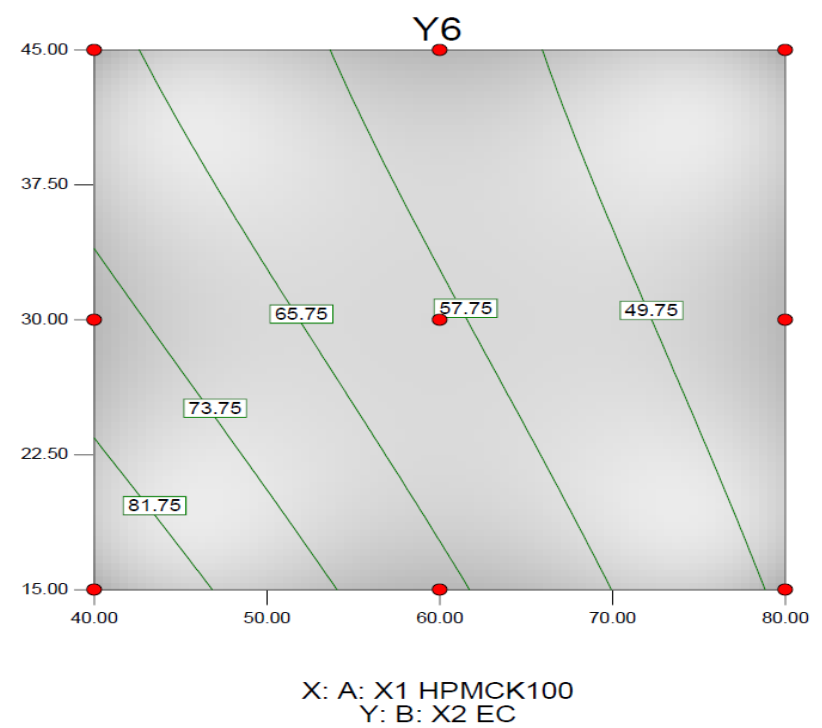

Fig. 18: Related contour plot indicating various levels of HPMC $\mathrm{K}_{100} \mathrm{M}$ and Ethyl Cellulose
DESIGN-EXPERT Plot

$Y 12$

$X=A: X 1$ HPMCK100

$Y=B: X 2 E C$

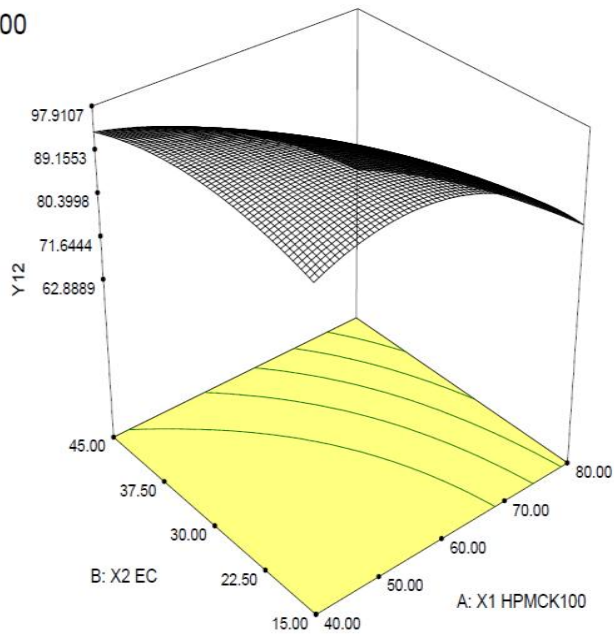

Fig. 19: Surface design of response $\mathrm{Y} 12 \%$ by varying quantities of HPMC $\mathrm{K}_{100} \mathrm{M}$ and Ethyl Cellulose

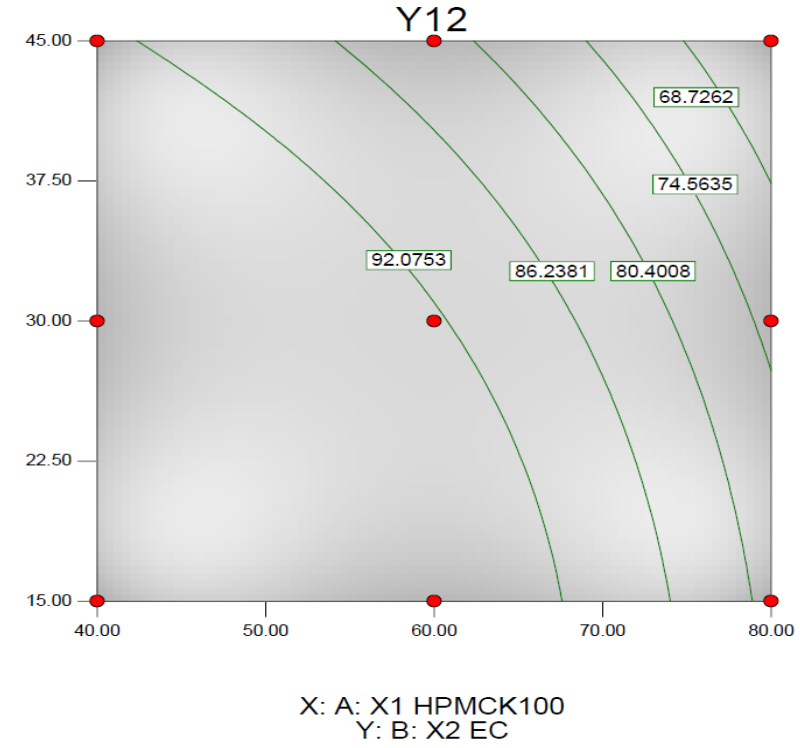

Fig. 20: Related contour plot indicating various levels of HPMC $\mathrm{K}_{100} \mathrm{M}$ and Ethyl Cellulose

The oral floating matrix tablets of Ciprofloxacin Hydrochloride were formulated by Experimental design by using HPMC $\mathrm{K}_{100} \mathrm{M}$ and Ethyl Cellulose as the retardant polymers each with three different levels with an approach to increase gastric residence and thereby improve drug bioavailability. Floating Matrix tablets were prepared by direct compression method and prepared tablets were evaluated for weight variation, percentage friability, hardness and drug content studies. All the formulations showed compliance with pharmacopeia standards. Floating lag times of all the formulations were within 1 minute and Total floating time of all the formulations were more than 12 hours. In vitro release studies revealed that the release rate decreased with increase polymer proportion of retarding polymers. The formulations $\mathrm{CHE}_{9}$ sustained release of drug for 12 hours with $21 \%$ release of drug after $1 \mathrm{hr}$ and more than $97 \%$ at the end of 12 hours. From the Kinetic model it was found that 
the optimized formulation $\mathrm{CHE}_{9}$ showed linearity in case of Zero order ( $\mathrm{R}^{2}$ : 0.938$)$ and Higuchi model ( $\mathrm{R}^{2}$ : 0.954). By fitting data to Korsmeyer-Peppas model and ' $\mathrm{n}$ ' value lying above 0.5 indicating non Fickian release. It can be concluded that stable formulation could be developed by incorporating in a definite proportion of HPMC and Ethyl Cellulose, along with definite amount of gas generating agent (Sodium bicarbonate), So that oral floating matrix profile is maintained for an extended periods of time.

\section{ACKNOWLEDGEMENTS}

The authors thanks to Royal College of Pharmacy \& Health Sciences, Berhampur, Odisha, for providing required facilities to carry out this research work.

\section{REFERENCES}

1. Bhatt P, Khatri N, Kumar M, Baradia D, Misra A. Microbeads mediated oral plasmid DNA delivery using polymethacrylate vectors: an effectual groundwork for colorectal cancer. Drug delivery, 2015; 22(6): 849-61.

2. Priyanka V, Reddy PSC, Sowmya C, Singh RK. Review article floating tablet and it's technology. Int J Pharma Drug Anal 2014; 2(8): 653-657.

3. Kataria S, Middha A, Bhardwaj S, Sandhu P. Floating drug delivery system a review. Int Res J of pharmacy 2011; 2(9): 1824.

4. Venketasurlu K, Jami KP, Badithala SSK. Floating drug delivery system of ciprofloxacin $\mathrm{HCl}$. Asian J Pharma 2016; 10(4): 271-278.

5. Bhatt P, Lalani R, Vhora I, Patil S, Amrutiya J, Misra A, Mashru R. Liposomes encapsulating native and cyclodextrin enclosed Paclitaxel: Enhanced loading efficiency and its pharmacokinetic evaluation. International Journal of Pharmaceutics. 2018; 536: 95-107.

6. Yewale C, Baradia D, Patil S, Bhatt P, Amrutiya J, Gandhi R, Kore G. Docetaxel loaded immunonanoparticles delivery in EGFR overexpressed breast carcinoma cells. Journal of Drug Delivery Science and Technology. 2018; 45: 334-345.

7. Patel J, Amrutiya J, Bhatt P, Javia A, Jain M, Misra A Targeted delivery of monoclonal antibody conjugated docetaxel loaded PLGA nanoparticles into EGFR overexpressed lung tumor cells. Journal of Microencapsulation. 2018; 35(2): 204-217.

8. Abbas N, Ahsan M, Hussain A, Saeed H, Shah PA, Mohammad S, Arshad MS. Formulation Optimization and In-vitro Evaluation of Oral Floating Captopril Matrix Tablets using Factorial Design. Tropical J Pharma Res. 2015; 14(10): 1737-1748.

9. Costa P, Sousa Lobo JM. Modeling and comparison of dissolution profiles. Eu J Pharma Sci. 2001; 13: 123-133.

10. Varshosaz J, Tavakoli N, Kheirolahi F. Use of hydrophilic natural gums in formulation of sustained-release matrix tablets of tramadol hydrochloride. AAPS Pharm Sci Tech. 2006; 7(1): E1-E7.

11. Shoaib MH, Tazeen J, Merchant HA, Yousuf RI. Evaluation of drug release kinetics from Ibuprofen matrix tablets using HPMC. Pak J Pharm Sci 2006; 19(2): 119-124.

12. Devarajan K, Rangasamy M, Selvaraj J and Natesan SK. Development and evaluation of floating tablets of ciprofloxacin $\mathrm{HCl}$. Int. journal of pharm and allied sciences archive. 2012 april-june; 1(1):17-25.

13. Reddy KR, Mutalik S, Reddy S. Once-daily sustained-release matrix tablets of Nicorandil: Formulation and in vitro evaluation. AAPS Pharm Sci Tech. 2003; 4 (4): 1-9.

14. Khemariya P, Jain AK, Bhargava M, Singhai SK, Goswami S, Goswami R. Preparation and in-vitro evaluation of sustainedrelease matrix tablets of Diltiazem. Int J Adv Pharm Sci. 2010; 1: $267-273$. 